\title{
Strategi Bauran Pemasaran Freeze Communication Dalam Event Pameran Kuliner Di Yogyakarta
}

\author{
Ubaidillah $^{1}$, Saghifa Fitriana ${ }^{2}$ \\ AMIK BSI Jakarta ${ }^{1}$, STIMIK Nusa Mandiri Jakarta ${ }^{2}$ \\ E-mail : ubaidillah.ubl@bsi.ac.id ${ }^{1}$, saghifa.sf@@nusamandiri.ac.id ${ }^{2}$
}

\begin{abstract}
Freeze Comunication is an event organizer that held various events both local scale and national scale located in Ngaglik Sleman Yogyakarta. Freeze Comunication has held various events such as music events, culinary, cultural titles, education, technology and so on. The goal is to improve the company's results through increasing the sales of each event, then the purpose of the most important promotional event that is to cause action from prospective buyers. Event organizers must have marketing mix concepts that are expected to help to be able to encourage sales of products / services of a company. the success of marketing activities undertaken depends not only on the quality of the products produced, the right policies, the services and the rapid distribution, but much influenced by the fostering of relations between producers and consumers sustainable. This research uses qualitative approach. Qualitative research is a research procedure that produces descriptive data in the form of written or oral words of people and behavior that is always observed. This qualitative research relates to the ideas, perceptions, opinions or beliefs of the people with the aim of obtaining a complete picture of things in human terms in this study. The result of this research is that Freeze Comunication in conducting culinary event has run a proper marketing mix strategy both to determine the quality of production on display, the price of traditional culinary products is cheap, affordable, community, promotion done both through social media and conventionally, the place strategic culinary exhibition events and access roads to fine exhibitions then wide land and able to bring in many buyers or communities.
\end{abstract}

\section{Keyword : Marketing Mix, Culiner, Event Organizer}

Abstrak: Freeze Comunication merupakan sebuah event organizer yang mengadakan berbagai event baik berskala lokal dan skala nasioanal yang berada di Ngaglik Sleman Yogyakarta. Freeze Comunication telah mengadakan berbagai event seperti acara music, kuliner, gelar budaya, pendidikan, teknologi dan sebagainya. Tujuanya adalah untuk meningkatkan hasil perusahaan melalui peningkatkan hasil penjualan setiap event, maka tujuan acara promosi yang paling penting yakni untuk menimbulkan tindakan dari calon pembeli. Event organizer harus mempunyai konsep-konsep bauran pemasaran yang diharapkan membantu agar mampu mendorong penjualan produk/ jasa suatu perusahaan. suksesnya kegiatan marketing yang dilakukan tidak hanya bergantung pada kualitas produk yang dihasilkan, kebijakan yang tepat, pelayanan serta distribusi yang cepat, tetapi banyak dipengaruhi oleh pembinaan hubungan antara produsen dan konsumen yang berkelanjutan. Penelitian ini menggunakan pendekatan kualitatif. Penelitian kualitatif adalah prosedure penelitian yang menghasilkan data deskriptif yang berupa kata-kata tertulis atau lisan dari orang-orang dan perilaku yang selalu diamati. Penelitian kualitatif ini berkaitan dengan ide, persepsi, pendapat atau kepercayaan dari masyarakat dengan tujuan untuk memperoleh gambaran seutuhnya mengenai hal menurut pandangan manusia dalam penelitian ini. Hasil dari penelitian ini bahwa Freeze Comunication dalam mengadakan event kuliner telah menjalankan strategi bauran pemasaran yang tepat baik untuk menentukan kualitas produksi yang dipamerkan, harga dari produk kuliner tradisional cukup murah, terjangkau ,masyarakat, promosi yang dilakukan baik melalui media sosial dan secara konvensional, tempat event pameran kuliner strategis dan akses jalan menuju pameran baik kemudian lahan luas dan mampu untuk mendatangkan banyak pembeli atau masyarakat.

Kata kunci : Bauran pemasaran, kuliner, event organizer

\subsection{Latar Belakang} Perdagangan

perusahaan diseluruh yang dilakukan mempunyai satu keyakinan, yaitu suksesnya kegiatan marketing yang dilakukan tidak hanya bergantung pada kualitas produk yang dihasilkan, kebijakan yang tepat, pelayanan serta distribusi yang cepat, tetapi banyak dipengaruhi oleh pembinaan hubungan antara produsen dan konsumen yang berkelanjutan. Promosi merupakan salah satu variabel dalam bauran pemasaran yang sangat penting dilakukan oleh perusahaan dalam memasarkan produk atau jasa. Menginggat persaingan pasar yang sangat ketat, dan untuk menarik minat konsumen untuk menjadi fanatik, setia dan tidak beralih ke produk yang lain maka diperlukan sesuatu yang khusus, 
unik, spesifik, dan diperlukan suatu unsur tematik dalam berbagai promosi.

Menurut Kloter (2001 : 98) jenis kegiatan promosi meliputi advertising, personal selling, publisity, sales promotion dan direct marketing dibutuhkan oleh sebuah perusahaan agar dapat berkembang serta perusahaan dapat melakukan aktivitas baik secara below the line yang merupakan aktivitas marketing atau promosi yang dilakukan ditingkat retail/konsumen dengan salah satu tujuannya adalah merangkul semua konsumen supaya eware dengan produk perusahaan dan aktivitas secara above the line yakni aktivitas marketing yang biasanya dilakukan oleh manajemen pusat sebagai upaya membentuk brand image yang diinginkan. Dalam mewujudkan kesuksesan sebuah promosi dibutuhkan kerja keras dan pemikiran yang matang. Mulai dari perrencanaan, persiapan, pendanaan sampai prosedur teknis kegiatan promosi itu sendiri dari awal sampai akhir, dan pada intinya aktivitas below the line selalu bertujuan untuk mendukung follow up aktivitas above the line.

Event Organizer adalah usaha dalam bidang jasa yang ditunjuk secara resmi oleh perusahaan atau perorangan untuk mengorganisasikan rangkaian acara, dimulai dari proses pembuatan konsep, perencanaan, persiapan, eksekusi, hingga rangkaian secara selesai dalam rangka membantu mewujudkan tujuan yang diharapkan melalui rangkaian acara yang diadakan. Impact yang diinginkan dari sebuah bentuk acara promosi yang diadakan adalah jumlah pengetahuan tentang produk ( product knowledge) yang dicapai konsumen melalui tingkat keterlibatan (involvement) konsumen dengan produk atau proses pemilihan. Konsumen memiliki tingkat pengetahuan produk (level of product knowledge) yang berbeda-beda yang dapat digunakan untuk menerjemahkan informasi baru dan membuat pilihan pembelian. Keterlibatan konsumen mengacu pada persepsi konsumen tentang pentingnya atau relevansi personal suatu objek, kejadian atau aktivitas. Konsumen yang melihat suatu produk memiliki konsekeuensi yang relevan secara pribadi, maka konsumen dikatakan terlibat dengan produk tersebut dan memiliki hubungan dengan suatu produk atau suatu merek memiliki aspek kognitif maupun pengaruh.

Permasalahan yang dihadapi pada setiap event kesiapan SDM yang sudah direncanakan namun dalam praktiknya ada beberapa yang belum paham mengenai job deskripsinya, kemampuan promosi pada event tertentu yang kadang belum sampai memikirkan dampak negatifnya dan pihak yang mengadakan kerjasama juga banyak ikut campur pada event

Freeze Comunication telah mengadakan berbagai event seperti acara Music, kuliner, gelar budaya, pendidikan, teknologi dan sebagainya. Tujuan akhir dari pemasaran adalah untuk meningkatkan hasil perusahaan melalui peningkatkan hasil penjualan setiap event, maka tujuan acara promosi yang paling penting yakni untuk menimbulkan tindakan dari calon pembeli. Event organizer harus mempunyai konsep-konsep bauran pemasaran yang diharapkan membantu agar mampu mendorong penjualan produk/ jasa suatu perusahaan.

\subsection{Tinjauan Pustaka}

\subsubsection{Pemasaran}

Menurut W.J. Stanton dalam (Murzid, 2011) Pemasaran adalah sistem yang berhubungan dengan kegiatan-kegiatan usaha, yang bertujuan merencanakan, menentukan harga, hingga mempromosikan dan mendistribusikan barang-barang atau jasa yang akan memuaskan kebutuhan pembeli, baik aktual maupun yang potensial.

Kegiatan utama dalam pemasaran adalah 4P, yakni Product : produk yang menyangkut pemilihan barang atau jasa yang ditawarkan secara tepat. Price : Penetapan harga jual yang sesuai dengan kualitas barang dan dapat dijangkau oleh konsumen. Place : Menyangkut pemilihan cara pendistribusian barang dan jasa sehingga sampai ketangan konsumen. Promotion : Yakni menyakut pemilihan kebijaksanaan promosi yang tepat, sesuai dengan barang atau jasa yang ditawarkan.

\subsubsection{Pengertian segmen pasar}

Menurut Kotler dalam Sunyoto (2014: 57) segmentasi pasar yaitu usaha pemisahan pasar pada kelompok-kelompok pembeli menurut jenis-jenis produk tertentu dan yang memerlukan bauran pemasaran tersendiri. Segmentasi pasar ini berdasarkan a).Segmentasi pasar geografis yang membagi pasar ke dalam unit-unit baik negara, propinsi, daerah, kota dan desa. b). Segmentasi pasar demografi merupakan pembagian pasar ke dalam kelompok berdasarkan variabel seprti usia, jumlah penduduk, jumlah keluarga, pendidikan dll, c) Segmentasi pasar psikologis, para pembeli dibagi ke dalam kelompok sosial, gaya hidup dan kepribadian.

\subsubsection{Culinary}

Culinary dalam bahasa Inggris berarti hal urusan dapur yang berkenaan dengan keahlian masak-memasak dalam bahasa Indonesia diistilahkan dengan kata kuliner. 
Pusat kuliner merupakan tempat makan dengan banyak stand makanan sehingga pengunjung bebas memilih, baik makanan maupun tempat makannya. Tata ruang pada pusat kuliner setara dengan food court. Food court adalah suatu tempat makan dengan counter-counter yang terdiri dari berbagai penjual makanan serta disediakan suatu area umum untuk self-servedining.

Perabot untuk keperluan food court harus praktis, nyaman dipakai serta sedap dipandang. Untuk tiap outlet atau bagian dari ruang makan sengaja dibuat berbeda, sesekali perlu diubah susunanya untuk mengubah atmosfir atau suasana agar tidak membosankan dan selalu menarik. Material bangunan yang umum digunakan dalam food court adalah ubin, formica, baja tahan karat, dan gelas/kaca. Semua bahan ini merupakan bahan yang mudah dibersihkan.

Perkembangan wisata kuliner cukup pesat terutama di DIY. Menurut Suriani $(2009 ; 12)$ menjelaskan bahwa culinary tourism is not prentious for exclusive. It includess any unique and memorable gastronomic experience, not just restaurant rate four star or better and include both food and all type of beverage.pernyataan tersebut dapat dimaknai bahwa wsiata kuliner bukanlah hal yang mewah dan exsklusif, dan wisata kuliner menekankan pada pengalaman bukan pada kemewahan dan restoran maupun kelengkapan jenis makanan atau minuman yang tersedia.

Wisata kuliner lokal merupakan produk makanan yang sering dikomsumsi oleh suatu kelompok masyarakat yang dihidangkan dalam perayaan dan waktu tertentu, diwariskan dari generasi kegenerasi , dibuat sesuai dengan resep secara turun temurun, dibuat tanpa atau dengan sedikti rekayasa dan memiliki karakteristik tertentu yang membedakan dengan kuliner daerah lain.(Guerrero,2010;40).

\subsubsection{Strategi Manajemen}

Strategi merupakan rencana fundamental untuk menetapkan arah keseluruhan dari suatu unit bisnis dalam mecapai arah tujuan perusahaan yang sudah ditetapkan (Alma dalam Yulianto, 2015:298). Menurut Wheelen dan Hunger, 2004 dalam Solihin (2009 : 83). Strategi manajemen merupakan serangkaian keputusan dan tindakan manajerial yang akan menentukan kinerja jangka panjang perusahaan. Tujuan utama pembuatan strategi melalui proses manajemen strategik oleh perusahaan yang didalamnya menyangkut berbagai keputusan strategik.

Dalam melakukan pekerjaan dan pada saat mereka mengelola dapat dikelompokan ke dalam kelompok tugas yang memiliki tujuan. Fungsi manajemen ini yang dijalankan oleh manajer pertama Planning yaitu suatu proses untuk mengembangkan tujuan perusahaan serta memilih serangkain strategis untuk mencapai tujuan tersebut, kedua Organizing yakni suatu proses dimana karyawan dan pekerjaannya saling dihubungkan untuk mencapai tujuan, ketiga Staffing yakni suatu proses untuk memastikan bahwa karyawan yang kompeten dapat dipilih, keempat Leading yakni suatu proses untuk memotivasi individu atau kelompok dalam suatu aktivitas yang hubungan kerja agar mereka dapat bekerja dengan sukarela (voluntarily) dan harmonis dalam mencapai tujuan perusahaan dan kelima controlling yang merupakan suatu proses untuk memastikan adanya kinerja yang efisien dalam pencapain tujuan perusahaan

\subsection{Metode Penelitian}

Penlitian ini dilakukan dengan menggunakan metode deskriptif, yaitu penelitian yang berusaha untuk mendeskripsikan atau mengambarkan fenomena yang diteliti secara sistematis faktual dan akurat (Kusmayadi,2000). Penelitian kualitatif ini berkaitan dengan ide, persepsi, pendapat atau kepercayaan dari masyarakat dengan tujuan untuk memperoleh gambaran seutuhnya mengenai hal menurut pandangan manusia dalam penelitian ini. Dalam enelitian kualitatif ini peneliti memiliki alat penelitian yang utama, adalah peneliti banyak mempunyai kelebihan dari pada daftar pertanyaan yang diberikan kepada masyarakat. (Sulistyo, Basuki, 2000). Untuk mencapai tujuan itu teknik pengumpulan data diambil dari teknik observasi, wawancara, dokumentasi serta studi pustaka, hal ini dapat dianalisis dari data yang telah diambil kemudian diolah sampaii dapat diambil kesimpulan.

\subsection{Hasil Penelitian Dan Pembahasan \\ 4.1.1. Freeze Communication}

Freeze Communication adalah salah satu perusahaan yang bergerak dibidang jasa event organizer, di Yogyakarta, dimana bentuk kerjanya mengorganisasikan rangkaian acara, dimulai dari proses pembuatan konsep, perencanaan, persiapan, eksekusi hingga rangkaian acara selesai dalam rangka membantu mewujudkan tujuan yang diharapkan melalui rangkaian acara yang diadakan. Perusahan yang berdiri sejak sejak tahun 2008 ini sangat memperhatikan kualitas baik dari produk dan jasa. Lokasi Freeze Communication di Perum Minomartani Jl. Lele 
3 No. 2 Ngaglik Sleman Yogyakarta, lokasi yang strategis, karena berada di Pinggiran Kota Yogyakarta. Freeze Comunication dalam menjalankan kegiatannya memiliki Visi dan Misi perusahaan yakni :

Visi :

Menjadi perusahaan nasional event organizer pilihan utama konsumen berbasis kreatifitas dan inovasi terbaru, keunggulan layanan dan sumber daya manusia yang

Misi : profesioanal.

1. Fokus pada kepentingan klien dalam menyampaikan keunggulan kepada pelanggan maupun calon pelanggan.

2. Menggali dan memahami perubahan kebutuhan pelanggan para klien

3. Mengembangkan cara-cara komunikasi yang tepat kepada pelanggan dan menyajikan variasi media marketing, advertaising, event organizer dengan perilaku kreatif dan inovatif

4. Mengutamakan kualitas produk dan pelayanan sejak persiapan event sampai pasca event

5. Meningkatkan kualitas, semangat, integritas, keterampilan dan kesejahteraan sumber daya manusia

\subsubsection{Sumber Daya Manusia}

Dalam menjalankan aktivitasnya seharihari Freeze Communication tentunya membutuhkan tenaga kerja yang profesional sehingga dapat mempekerjakan karyawan yang memiliki standar dan kualitas tertentu. Sumber Daya Manusia yang digunakan oleh Freeze Cimmunication yakni : Project Officer/ Event Manajer, Field Officer, Tallent Officer. Show Officer, Art Director, Stage Manajer, Sound Engineer/Soundman, Ligthingman, Security, Runner. Jika event berskala menengah ada fungsi lain terutama dalam event indoor maupun outdoor yakni ada Program leader, Project Officer, Class leader, Talent, Observer, Operator, Safety Officer, Medis.

\subsubsection{Persaingan}

Persaingan tentu saja dialami oleh Freeze Communication, terutama dalam hal mendapatkan sponsor untuk mendukung suatu bentuk acara yang diadakan. Dari sini dapat dilihat bagaimana sebuah event organizer harus memiliki ide-ide kreatif yang menghadirkan konsep yang benar-benar matang, sehingga pihak sponsor maupun klien tertarik untuk mendukung sebuah acara.
Konsep dalam sebuah acara bagi Freeze Communication adalah hal yang sangat vital. Konsep dari sebuah ide-ide kreatif adalah langkah pertama sebuah event organizer dan merupakan penentu langkah berikutnya. Karena dengan mengandalkan konsep yang telah ditawarkan, setiap event organizer mencoba memberikan visi dan misi acara yang akan dibuat. Ditambah dalam lima tahun terakhir bisnis event organizer sangat berkembang pesat, banyak permintaan dari perusahaan untuk menangani kegiatan perhotelan mereka saat ini, mendorong munculnya beragam lembaga yang bergerak $\mathrm{di}$ bidang event organizer.

Kemudahan yang ditawarkan oleh bermacam event organizer pun kini berubah menjadi semcam kebutuhan. Kapan saja sebuah lembaga, perusahaan atau person menginginkan terselenggaranya sebuah acara, maka event organizer menjadi solusi yang paling mudah. Dengan kata lain, persaingan bisnis event organizer bertambah ketat seiring munculnya pandangan bahwa banyak kesempatan untuk meraup keuntungan di bisnis event organizer.

Bagi Freeze Communication kendala dan persaingan tersebut tidaklah menjadi masalah yang harus ditakuti, namun dipandang sebuah tantangan bagi Freeze Communication untuk bisa menghasilkan ideide kreatif untuk dituangkan kedalam sebuah konsep suatu acara yang menarik. Mewujudkan kesuksesan sebuah acara merupakan sebuah kerja keras dan dibutuhkan konsep yang benar-benar matang. Bagi Freeze Communication sudah tidak dapat ditawar lagi bahwa tanpa ada konsep yang jelas dan terarah, tentu saja acara tidak bisa berlangsung dengan sukses.

\subsubsection{Konsumen}

Bagi event organizer konsumen biasa disebut klien, biasanya klien itu berasal dari sebuah pemerintahan, perusahaan hingga perseorangan. Dalam hal ini event organizer pertama harus menempatkan dirinya sebagai pemberi gagasan suatu jasa, untuk menyampaikan suatu gagasan event organizer harus mengenal identitas calon sponsor. Dalam memahami identitas calon sponsor event organizer harus mengerti produk yang ditawarkan, dimulai dari segmentasi, targetting hingga positioning suatu klien. Maka suatu evet organizer harus berusaha mengenali harga dan gaya iklan-iklan sehingga gagasan event organizer berkesinambungan dengan model-model acara yang klien inginkan.

Freeze Communication juga membagi dua kategori klien atau konsumen mereka 
menjadi 2 (dua) yaitu, konsumen langsung dan tidak langsung.

1. Konsumen langsung

Konsumen langsung Freeze

Communication adalah konsumen atau klien yang melakukan transaksi langsung dengan Freeze Communication tanpa perantara. Misalnya suatu perusahaan A ingin mengadakan suatu launching produk dan langsung menghubungi Freeze Communicatin dalan penanganan eventnya. Jadi terjadi kesepakatan langsung dikedua belah pihak antara perusahaan A dengan Freeze Communication.

2. Konsumen tidak langsung

Konsumen tidak langsung adalah konsumen atau klien Freeze Communication yang melakukan transaksi bukan dengan Freeze Communication melainkan dengan seorang perantara atau sebuah agen. Misalnya sebuah agen penjualan diminta perusahaan B untuk melakukan direct marketing produknya, agen tersebut menghubungi dan diminta untuk melaksanakan event tersebut namun Freeze Communication harus memakai brand atau nama perusahaan agen tersebut.

Dibawah ini dapat dilihat bagan jalur transaksi konsumen dan freeze communication :

1. Konsumen lansung

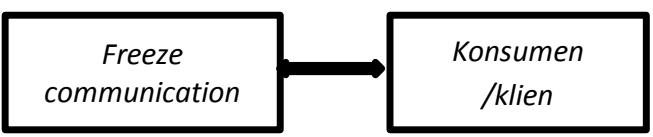

Gambar 1: Jalur transaksi konsumen Langsung

2. Konsumen tidak langsung

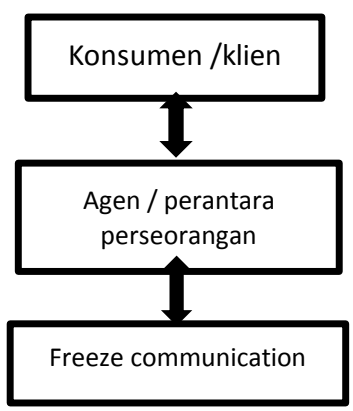

Gambar 2: Jalur transaksi konsumen tidak langsung

\subsubsection{Marketing Mix}

Bentuk alat-alat pemasaran yang meliputi beberapa komponen pemasaran yang biasa disebut bauran pemasaran (marketing mix), meliputi:

1. Produk
Produk yang dihasilkan Freeze Communication adalah bentuk sebuah jasa. Kembali ke latar belakang event organizer adalah usaha dalam bidang jasa yang ditunjuk secara resmi oleh perusahaan atau perseorangan untuk mengorganisasikan rangkaian acara, dimulai dari proses pembuatan konsep, perencanaan, persiapan, eksekusi hingga rangkaian acara selesai dalam rangka membantu mewujudkan tujuan yang diharapkan melalui rangkaian acara yang diadakan.

Dari pengertian diatas Freeze Communication menghasilkan suatu jasa berupa suatu gagasan hingga berperan menjadi eksekutor sebuah event. Ada beberapa jenis acara yang sering dikerjakan oleh Freeze Communication, baik itu acara musik, lauching produk, pameran (exebition), acara olahraga, pelantikan dan lain sebagainya. Dalam pelaksanaannya Freeze communication selalu mengacu pada kegiata education, entertainment dan exhibition, dimana sebuah acara harus mampu dan memiliki unsur mendidik, menghibur, memamerkan. Sehingga dari situ Freeze Communication dapat menghasilkan suatu produk yaitu jasa yang berkualitas. Produk yang dipameran dalam event kuliner sangat berbagai ragam terutama makanan tradisional yang menjadi daya tarik tersendiri sehingga masyarakat menikmati makanan kembali ke jaman dulu.

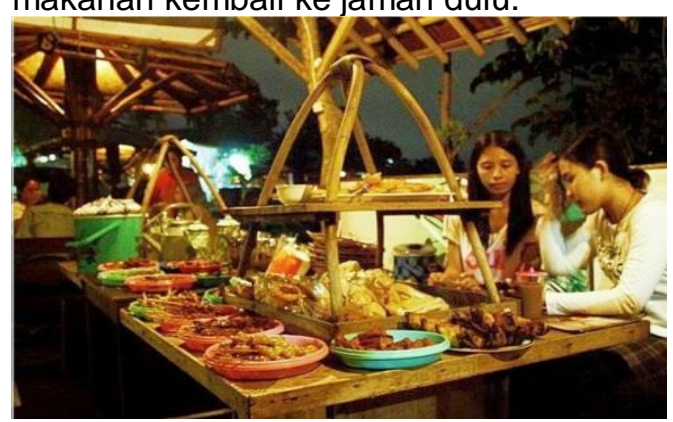

\section{Harga}

Gambar 3 : Kuliner Pelanggan

Harga bagi Freeze Communication yang ditawarkan biasanya tergantung pada acara yang ditawarkan atau event yang diinginkan konsumen atau klien yang bersangkutan. Dalam menetapkan harga Freeze Communication juga harus mempertimbangkan upah tenaga kerja, biaya promosi, produksi, transportasi baik itu dari supplier hingga outsource.

Bagi perusahaan yang sering menggunakan jasa Freeze Communication biasanya akan diberikan harga yang relative lebih rendah. Hal ini merupakan sala satu strategi perusahaan untuk 
memberikan nilai lebih bagi para pelanggan. Tapi harga yang ditawarkan bisa saja berubah setiap saat, karena seiring perubahan nilai mata uang dan kondisi ekonomi. Dalam menawarkan harga biasanya Freezee Communication akan memberikan table budget event yang akan diselenggarakan.

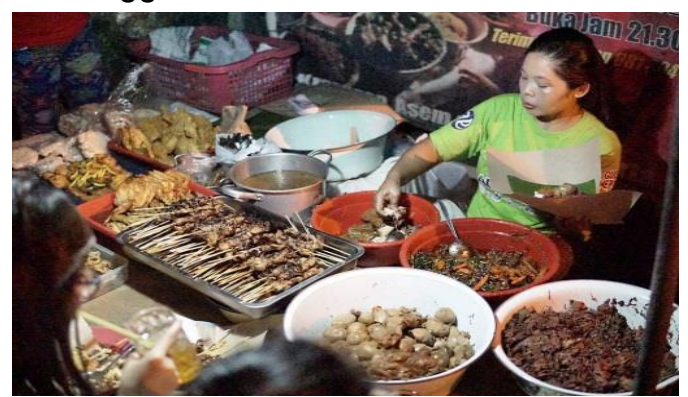

Gambar 4 : Aneka Jenis Menu Kuliner

\section{Promosi}

Kegiatan promosi perusahaan dilakukan secara terus menerus, sebab bagi Freeze Communication promosi merupakan hal yang paling utama dalam konsep dasar perusahaan. Freeze Communication adalah perusahaan yang bergerak dibidang penyelenggaraan sebuah acara dan merupakan suatu bentuk promosi sebuah perusahaan yang menggunakan jasa Freeze Communication. Maka jika Freeze Communication tidak memiliki kegiatan promosi dalam memasarkan jasa yang ditawarkan sama artinya perusahaan tidak mempunyai keahlian dibidangnya dan tidak akan mendapatkan pemasukan. Dalam kegiatan promosi Freeze Communication melakukan dengan menciptakan alamat browser berupa web yang dalam web Freeze Communication menjelaskan profil perusahaan hingga event yang pernah dilakukan, sehingga konsumen atau klien dengan muda mendapatkan informasi tentang Freeze Communication. Selain itu promosi juga dilakukan secara personal sellling dengan mendatangi langsung calon atau klien.

4. Place

Dalam penentuan lokasi atau tempat sangat dibutuhkan kejelian dan kecermatan dalam pemilihan lokasi disebabkan melihat segman tasi pasar atau segemen daya beli masyarakat disekitar lokasi pameran. Tempat merupakan faktor penting dalam mengadakan event sehingga tidak terjadi kerugian dan semuanya saling mendapatkan keberhasilan dan keuntungan.

\section{Distribusi}

Bagi sebuah event organiser seperti Freeze Communication kegiatan berupa distribusi tidak bisa lepas dalam pelaksanaan event yang dilakukan. Sebagai perusahaan event organizer, Freeze Communication juga sering menawarkan jasa dalam distribusi suatu produk sebua perusahaan. Sebuah acara yang dikerjakan perusahaan jasa seperti Frezee Communication disamping pekerjaan utama sebagai penyelenggara biasanya mengandung unsur publisitas pemasaran, langsung penjual personal.

Dalam menjalankan atau menyelenggarakan suatu acara yang diinginkan para klien, Freeze Communication tidak melupakan salah satu aspek marketing event, yaitu untuk memungkinkan perdagangan dalam entuk promosi. Sehingga tidak bisa dihindari bahwa Freeze Communication secara tidak sadar melakukan kegiatan distribusi. Misal perusahaan A meggunakan jasa Freeze Communication dalam menyelenggarakan acaranya di sebuah kota, dalam event Freeze Communication harus menyediakan sebuah transportasi mobil untuk membawa produk tersebut. Biasanya Feeze Communication juga melengkapi dengan menyediakan jasa SPG (Salaes Promotion Girl ) sebagai bentuk upaya membantu memberikan informasi tentang produk tersebut secara langsung sehingga produk dari perusahaan A mendapat timbal balik yang positif. Tapi dalam pelaksanaannya sengaja dirancang dan dikaitkan dengan kegiatan acara yang sedang berlangsung.

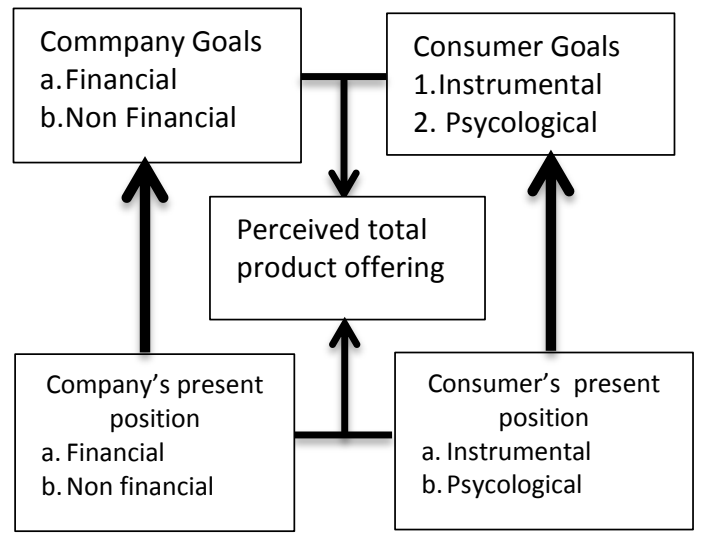

Gambar 5: Marketing Communication

\subsection{Kesimpulan}

Penerapan strategi bauran pemasaran di Freeze Communication sudah cukup baik, karena dari strategi yang dijalankan tersebut mampu membuat Freeze Communication menjadi salah satu perusahaan event organizer yang sudah tidak dipandang sebelah mata oleh perusahaan atau seseorang dalam mengorganisasikan sebuah rangkaian acara 
baik itu sebuah kegiatan Education, Entertainment dan Exhibition.

Event culiner sering digadakan di berbagai tempat, karena visata kuliner sangat diminati oleh kalangan muda, gololongan tua, golongna remaja. Hal ini secar berkelanjutan event kulinar ini sangat dibutuhkan okeh masyarakat lingkungn baik internal maupun eksternal.

Freeze Communication dalam kegiatan pameran kuliner, sangat mendukung bagi Usaha Kecil dan Menengah yang ada terutama didaerah Sleman. Peran Event Organizer ini cukup membantu dan meningkatkan promosi berbagai hal baik untuk event skala kecil, skala menengah maupun skala nasional.

Dalam mengadakan setiap event maka dibutuhkan strategi baik dapat ditinjau dari produksi atau jenis-jenis produk yang dipameran dalam wisata kuliner tersebut, Harga sangat penting dalam mengadakan event agar jenis produk dapat terjual semua dengan kemampuan masyarakat sekitar.

Promosi bagi setiap event tentunya membutuhan media inofrmasi untuk mengetahui seberapa besar event tersebut dan masyarakat akan datang melihat dan membeli produk terutama produk pameran makanan jenis tradisional.

\section{Daftar Pustaka}

[1] Kusmayadi, 2000. Metodologi Penelitian Dalam Bidang Kepariwisataan, Jakarta, Gramedia Kepustakaan.

[2] Mursid, 2011. Manajemen Pemasaran, Jakarta. Penerbit Bumi Akasara Jakarta

[3] Solihin,Ismail, $2009 . \quad$ Pengantar Manajemen. Jakarta, Penerbit Erlangga

[4] Sunyoto,2014. Dasar-dasar Manajemen Pemasaran, Jakarta : PT Buku Seru

[5] Suriani, Ni Made, 2009. Seni kuliner Bali sebgaai salah satu Daya tarik wisata, Denpasar, Univervitas Udayana

[6] Guerrero, 2010. Perception of tradisional food products in six european regions using free word association, food quality and preferience.Yogykaarta,Jurnal terapan UGM

[7] Kotler, philip dan amstrong, 2010. Principles of Marketing. New Jersey, Pearson Prentice Hall

[8] Sutisna,2002.Perilaku Konsumen dan Komunikasi Pemasaran. Bandung, PT.Rosdakarya

[9] Yulianto, Atun. 2015. Strategi Pemasaran PT. TWC Dalam Meningkatkan Kunjungan Wisatawan Dan Laba Usaha Pengelolaan Candi Borobudur, Prambanan Dan Ratu Boko. Jurnal Media Wisata Vol. 13 No. 2 November 2016. Yogyakarta : STP AMPTA 